\title{
Recurrent Oral Manifestations of Paracoccidioidomycosis without Pulmonary Involvement: Case Report and Review of Literature
}

\author{
Manifestación Oral Recurrente de Paracoccidioidomcosis sin \\ Compromiso Pulmonar: Reporte de Caso y Revisión de la Literatura
}

\begin{abstract}
Manuel Antônio Gordón-Núñez; ; Ana Luiza Dias Leite de Andrade"; Hugo Costa Neto"*; Eveline Pipolo Milán ${ }^{*+* t *}$; Kleber Giovanni Luz ${ }^{*+* * *}$ \& Hébel Cavalcanti Galvão ${ }^{*+*+* t}$
\end{abstract}

GORDÓN-NÚÑEZ, M. A.; ANDRADE, A. L. D.; COSTA NETO, H.; MILÁN, E. P.; LUZ, K. G. \& GALVÃO, H. C. Recurrent oral manifestations of paracoccidioidomycosis without pulmonary involvement: case report and review of literature. Int. $\mathbf{J}$. Odontostomat., 8(2):267-272, 2014.

\begin{abstract}
This article describes a case of recurrence of chronic paracoccidioidomycosis (PCM) 11 years following the initial diagnosis. The patient was a 51-year-old white Brazilian female, which had been previously diagnosed with PCM. The physical examination revealed the presence of a single crusted lesion in the upper lip and an elevated lesion with fibrous scar appearance on right buccal mucosa. Although the diagnosis of PCM, the absence of pulmonary involvement led to the biopsy of the lesion localized on the buccal mucosa and the histopathological analysis in H\&E and PAS stains revealed no morphological changes suggestive of any lesion. However, the exfoliative cytology stained with Grocott-Gomori showed the presence of Paracoccidioides brasiliensis and the infection caused by this fungus was proven. Of this way, we emphasize the importance of stomatologic evaluation to the diagnosis of diseases that usually manifestssystemically. So, the correct diagnosis of oral manifestations of PCM, is essential to ensure early and safe intervention.
\end{abstract}

KEY WORDS: paracoccidioidomycosis, paracoccidioides brasiliensis, oral mycosis, exfoliative cytology.

\section{INTRODUCTION}

Paracoccidioidomycosis (PCM) is a fungal infection caused by Paracoccidioides braziliensis (De Azevedo Izidoro et al., 2007). Other denominations were Brazilian Blastomycosis, and South American Blastomycosis. It is an endemic disease representing a serious health problem for Latin American countries, especially Ecuador, Colombia, Venezuela, Argentina and Brazil (Godoy \& Reichart, 2003; de Oliveira Gondak et al., 2012). This last country contributes with the highest incidence of the disease in the world, occupying the eighth place among causes of death from infectious, recurrent, chronic and parasite diseases
(Coutinho et al., 2002). It occurs more often in men than women, mainly after the third decade of life (De Azevedo Izidoro et al.; Neville et al., 2009).

The primary disease affects the lungs, and can spread to other organs and tissues, creating secondary lesions (Borges-Walmsley et al., 2002). It is reported that the occurrence of oral ulcers with mulberry-like appearance may be a frequent clinical manifestation of infection (Verli et al., 2005). The most frequent oral localizations are the alveolar mucosa, palate and gingiva. The other mucosal lining, adjacent to the oral

DDS, MSc, PhD, Professor, Oral Pathology, Department of Oral Pathology, State University of Paraíba, PB, Brazil.

* DDS, MSc, PhD student, Oral Pathology Postgraduate Program, Department of Dentistry, Federal University of Rio Grande do Norte,Natal, RN, Brazil.

*** Graduate Student of Dentistry, Federal University of Rio Grande do Norte, Natal, RN, Brazil.

MD, MSc, PhD, Professor, Division of Infectology, Giselda Trigueiro Hospital, Federal University of Rio Grande do Norte, Natal, RN, Brazil.

.**** DDS, MSc, PhD, Professor, Oral Pathology Postgraduate Program, Department of Dentistry, Federal University of Rio Grande do Norte, Natal, RN, Brazil. 
cavity can also be affected, including lips, tongue, oropharynx and buccal mucosa (de Oliveira Gondak et al.; Neville et al.). Although less common, the infection can invade oral bone tissue, causing complications such as perforation of the hard palate when the fungus is established in the maxilla (Castro et al., 2001).

The purpose of this article was to report a case of recurrent PCM without pulmonary involvement, but which presented oral manifestations. Furthermore, we discuss the main aspects related to the pathogenesis, clinical aspects and differential diagnosis of these lesions.

\section{CASE REPORT}

A 51-year-old white female, smoker since 14years old was referred to the Giselda Trigueiro Infectious-Contagious Diseases Hospital in Natal - RN, Brazil with main complaint of lesion on the upper lip with evolution of four months. The medical history revealed that 11 years prior, in the left zygomatic region a small erythematous and elevated lesion emerged for the first time, approximately $3 \mathrm{~cm}$ in diameter. At the same time, the patient related sudden and constant dysphagia and odynophagia. There was an increase in number and size of the lesions eventually occupying the whole face, with erythematous, infiltrative features, and some desquamative lesions. The patient denied any symptoms or signs in the respiratory tract, or fever and indicated she received medical attention in São Paulo. A laryngoscopy was performed and subsequent diagnosis of PCM was established. Amphotericin B + hydrocortisone were prescribed, followed by itraconazole, which was used intermittently, so it was changed to fluconazole. During the treatment period with fluconazole, the lesions recurred, with intermittent remissions and relapses for 9 years. Three years ago, the skin lesions appeared, associated with a single lesion in buccal mucosa, of approximately $2 \mathrm{~cm}$ in diameter, well demarcated, normal coloration in the central area and erythematous in the peripheral region, and with elevated borders and fibrous scar appearance. In that period the treatment with fluconazole was changed to sulfamethoxazole + bacitracin, with regression of mucocutaneous lesions. One year ago the mucocutaneous lesions recurred with the same features, occupying the entire face, trunk and limbs, with emphasis for erythematous lesions on face, small vesicles in the right fronto-zygomatic region and fibrous- atrophic lesion on mentonian area (Fig. 1A). Radiograph of the thorax showed normal pulmonary aspect (Fig. 1B). At the same time a single crusted lesion appeared, without secretion and with approximately $1 \mathrm{~cm}$ in diameter in the upper lip, which was atrophic (Fig. 2A). The patient related that the lesion increased in size promoting a limitation of mouth opening and difficulty in swallowing and phonation. There was also elevated lesion with fibrous scar appearance on right buccal mucosa (Fig. 2B), which was biopsied and the specimen was sent to the Pathological Anatomy Service, Discipline of Oral Pathology, Dentistry Department of UFRN in Natal RN. Histopathological analysis in hematoxylin and eosin (H\&E) and PAS stains revealed no morphological changes suggestive of PCM. In the hospital, material

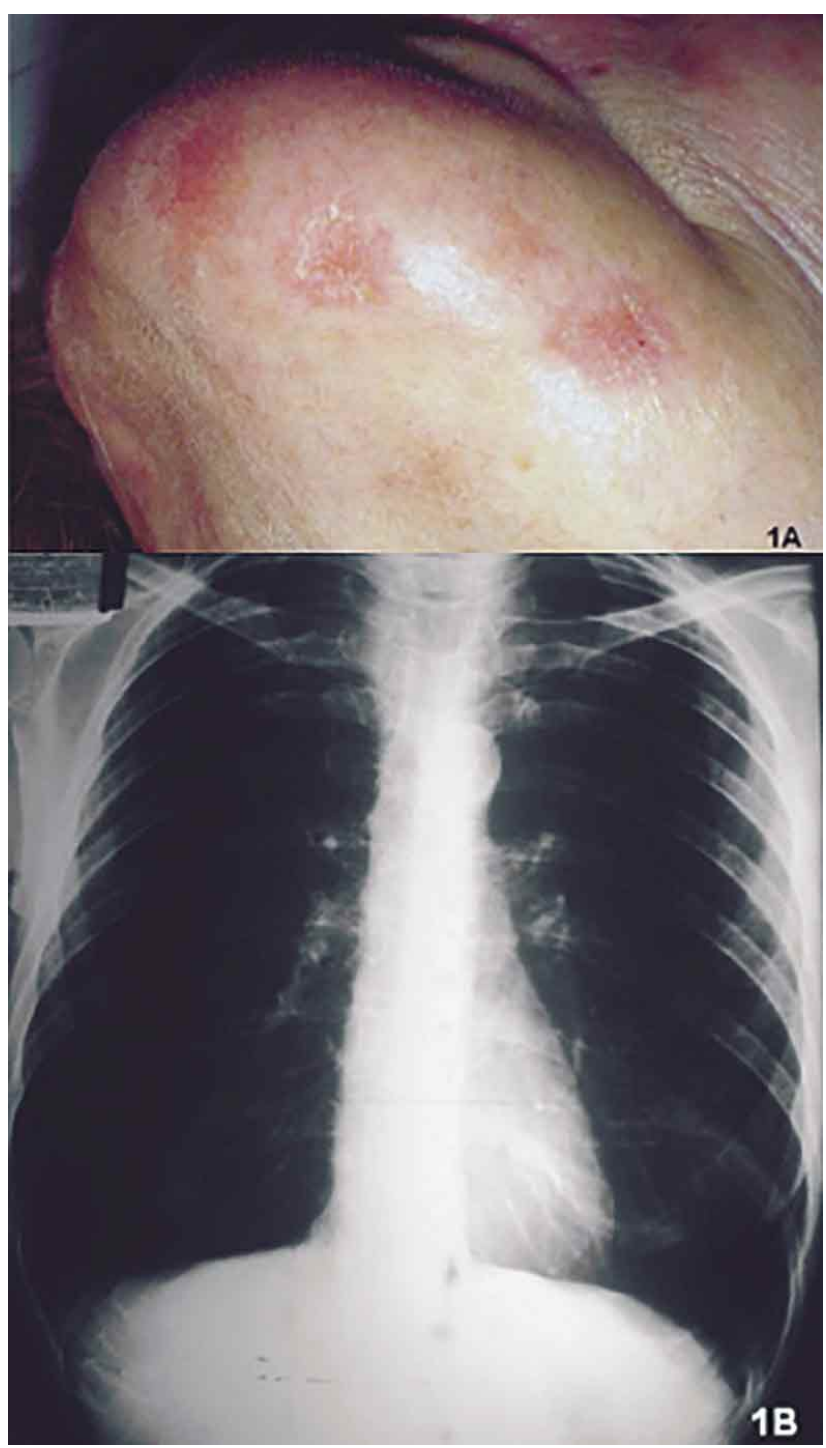

Fig. 1. (A) Fibrous-atrophic lesion on mentonian area, (B). Radiograph of the thorax showing normal pulmonary aspect. 
for cytological smear stained by Grocott-Gomori was collected. Microscopic analysis revealed the presence of P. brasiliensis as rounded refractile cells with multiple budding which appeared as double-contoured structures, often surrounded by daughter cells or blastoconidia (pilot-wheel aspect) (Fig. 3A). Based in the clinical features and cytological findings the diagnosis of PCM was established. The patient was treated with intra-venous liposomal amphotericin B (total dose of $1.950 \mathrm{~g}$ ), followed by oral itraconazole, prescribed during one year. At present, the patient presents good general health status, without activity lesions. She has only sequel lesions of microstomia and upper lip retraction (Fig. 3B).

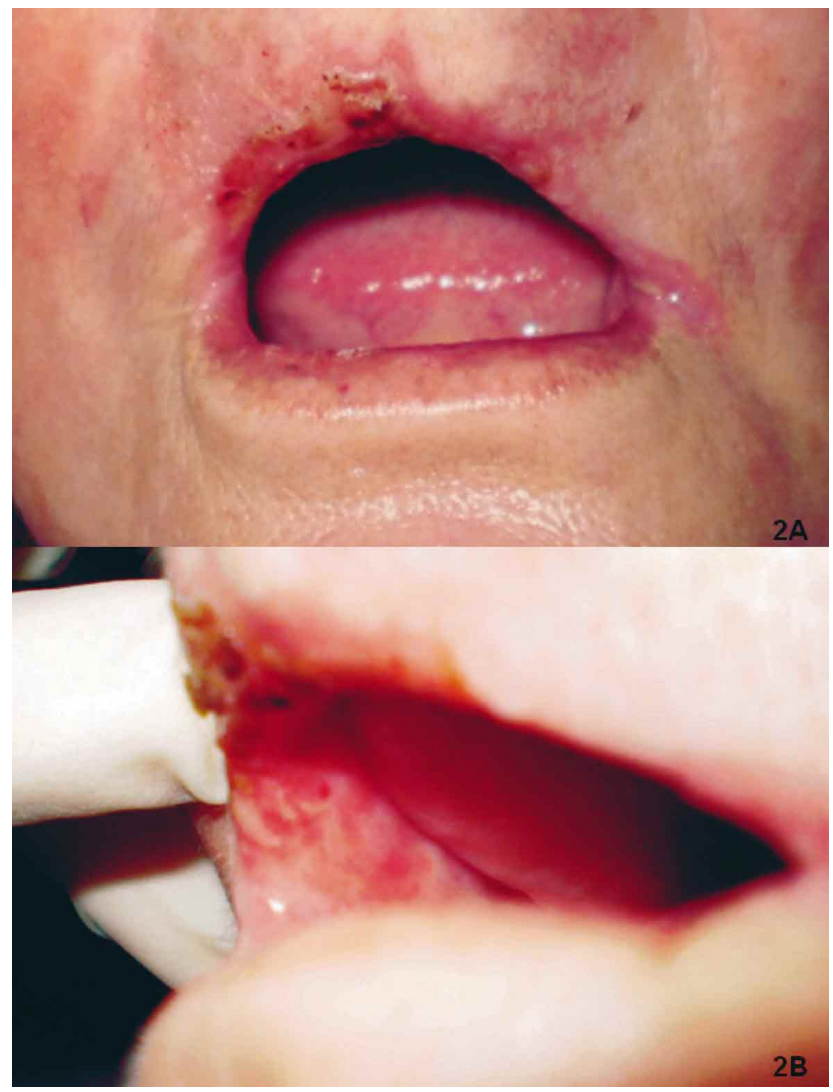

Fig. 2. (A) Crusted lesion in the upper lip promoting limitation of mouth opening and difficulty in swallowing and phonation, (B) Elevated lesion with a fibrous scar appearance on right buccal mucosa.

\section{DISCUSSION}

The etiologic agent of PCM, the dimorphic fungus Paracoccidioides brasiliensis is commonly found in Central and South America, where it is endemic in certain areas such as central and southeastern Brazil (Godoy \&

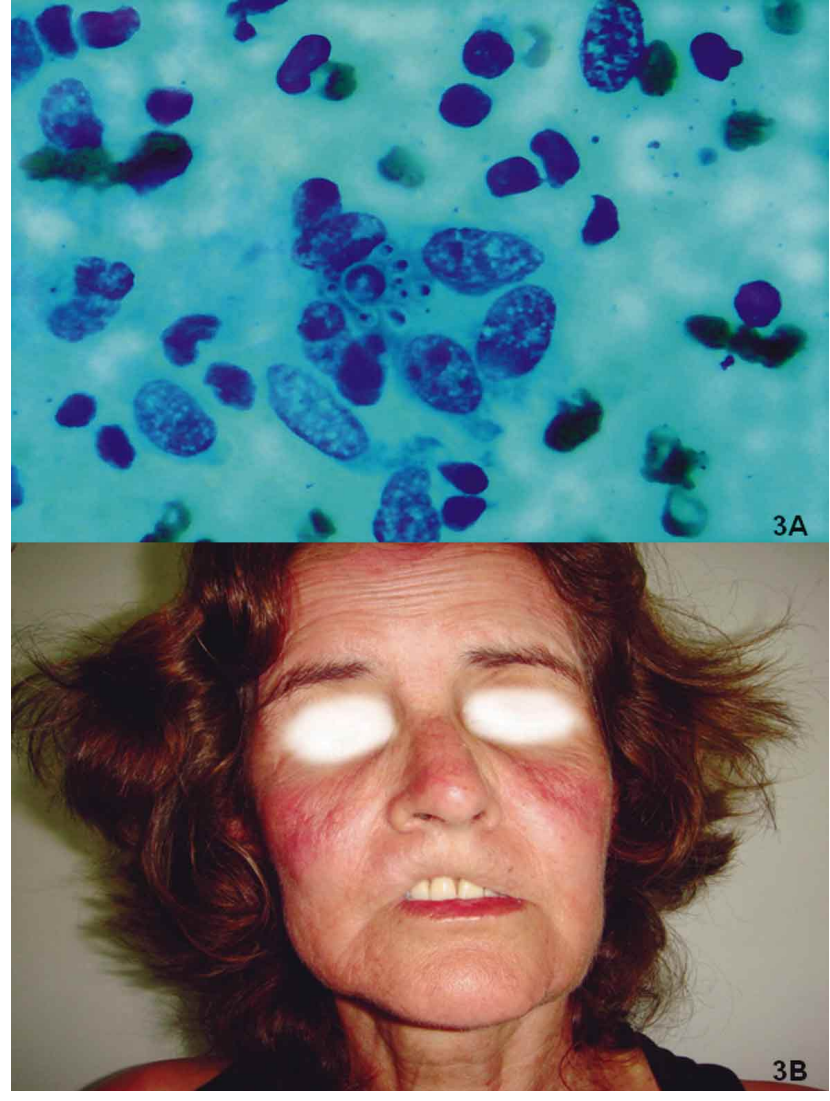

Fig. 3. (A) Cytological smear showing P. brasiliensis as rounded refractile cells with double contour, showing characteristic multiple budding (Grocott-Gomori x400), (B) Post treatment aspect of the patients: absence of cutaneous lesions, microstomia and upper lip retraction as sequel lesions.

Reichart; Bicalho et al., 2001), probably by the local soil conditions that offers ideal conditions for the growth of the fungus as humid, rich in organic materials, exuberant vegetation, and minimal variations of temperature from $200 C$ (Franco et al., 2000). Probably, the patient of this case acquired the infection in São Paulo-SP, a Brazilian southeastern city, where she lived years ago. Although the patient had always lived in urban areas, the infection may have been acquired through the inhalation of fungal conidia in vegetables produced in the rural area and marketed in urban zone.

The pathogenesis of PCM is initiated as a cellular immunologic response characterized by the activation of macrophages by components of $\mathrm{P}$. brasiliensis cell wall as the glycoprotein 43 (gp43) (Borges-Walmsley et al.; Romano et al., 2002), inducing production of TNF-a, IL-6 that acts to reduce the poisonous effect of TNF-a and stimulate the synthesis of antibodies by B 
lymphocytes, and IL-10 that acts to reduce the effectiveness of proinflammatory cytokines. The regulation of these cytokines is related to the persistence of the disease as a chronic form for a long period without systemic symptoms, such as fever and anorexia (Peraçoli et al., 2003). Besides the balance Th1/Th2 immune reaction, recent studies point to the presence of Treg and Th17 cells playing a role in the immune response against fungal infections (Pagliari et al., 2011).

In relation to the differences between sexes, the case reported in this article is in discordance with the literature since it occurred in a female patient. The low incidence of the disease in women is attributed to receptors for estrogen on P. braziliensis, once this female hormone inhibits transformation of the conidia to yeast form (Rubin \& Strayer, 2006). It is postulated that after menopause, women are more susceptible to PCM (Almeida et al., 2003). In addition, enhancing the information before mentioned, probably the age of the patient, the persistence and exacerbation of the lesions may have some association with increased susceptibility to infection.

Regarding oropharyngeal manifestations, usually the lips, gingiva, palate and buccal mucosa are involved typically characterized by swelling, hemorrhagic punctiform erosions, followed by ulcerations or erythematous finely granular hyperplasia, speckled with pinpoint hemorrhages and a mulberrylike surface called "moriform" stomatitis. Ulcerations can show an irregular surface with a granulomatous and/or proliferative aspect with elevated and indurated lesional margins. These ulcerations can be multifocal or single (Godoy \& Reichart). However, when the oral manifestation is single, others lesions, particularly squamous cell carcinoma, must be included in the differential diagnosis (de Oliveira Gondak et al., 2012).

The occurrence of primary oral lesions without lung involvement suggests that the infection can result from the inoculation of Paracoccidioides brasiliensis directly into the oral mucous membrane or could have been aspiration of conidia - primary fungemia and a unifocal cutaneous form, due to the location of the fungus on the skin and oral mucosa (Meneses-García et al., 2002) through the fungus colonization in the tissues after microorganisms adhere to laminin of oral mucosa basal lamina (Godoy \& Reichart; André et al., 2004; Roldán et al., 2001). In this case, the oral lesions were not the first manifestations of the disease, onset they were preceded by the cutaneous lesions.
It is recommended that even in individuals without signs of infection in the respiratory tract, a lung evaluation should be performed as the fungus could colonize lung septa without causing an evident lesion. This case is a chronic form of PCM as the lesions were of long duration (Almeida et al.). An unexpected finding in this case was the lack of lung involvement. Since the onset of the disease 11 years ago, no systemic involvement was observed, which was corroborated with a pulmonary radiographic evaluation.

Smoker patients had a relevant factor for decreasing local oral tissue resistance, contributing to the fungus penetration into the tissues. The case reported here coincided with this fact because she was a smoker since 14-years old (during a period of 37 years), with an average of 20 cigarettes per day. This fact, added to the compromise of the immune status of the patient probably contributed to increased risk of developing oral lesions and their recurrence.

Usually, the final diagnosis of PCM depends on the results of clinical evaluation and cytological diagnosis, supported by histopathology (Almeida et al.). However, the diagnosis of PCM by means of H\&E staining can be impaired by the difficulty in visualizing the fungus with this technique, and thus, GrocottGomori staining is used to better identify the pathogen in the tissues (de Abreu e Silva et al., 2013). In this case incisional biopsy of the lesion in buccal mucosa was performed for H\&E and PAS stains, but could not identify histopathological features suggestive of PCM. Probably, the small size of the biopsied specimen or problems with the tissue fixation contributed to the inconclusive final histopathological diagnosis. Based on the clinical features and peculiar findings of cytological analysis by Grocott-Gomoristained oral smear the diagnosis was conclusive for P. braziliensis. It report that cytologic diagnosis may be useful, but some authors consider histopathologic analysis essential for definitive diagnosis (Silva et al., 2007).

The therapeutics of PCM consists of support measures to the clinical complications associated with the involvement of different tissues by the mycosis and specific antifungal therapy, it is essential to submit the patient to regular monitoring and observation, the criteria of cure is based on clinical parameters, radiological and serological. The P. brasiliensis is sensitive to most antifungals, including the Sulfonamide. Consequently, since amphotericin B, Sulfonamide (sulfadiazine, combination trimethoprim / 
sulfamethoxazole) and azole (ketoconazole, fluconazole, itraconazole) may be used. It is also suggested that itraconazole as a therapeutic option would allow control of mild and moderate forms of the disease in a shorter period of time, in place of the drug (Shikanai-Yasuda et al, 2006). Oral lesions typically show an excellent response after a few weeks of treatment. After an initial 6-month course, long-term maintenance therapy is needed for 2 years (Almeida et al.; Van Damme et al., 2006).
In summary our case is important because it reports recurrent mucocutaneous manifestations of PCM in female without pulmonary involvement, emphasizing the importance of stomatologic evaluation to the diagnosis of disease that usually manifests systemically. Also, it highlights the importance of oral exfoliative cytology as a less invasive, faster, costeffective and helpful diagnostic tool for PCM, especially in endemic countries which are mostly developing countries as Brazil.

GORDÓN-NÚÑEZ, M. A.; ANDRADE, A. L. D.; COSTA NETO, H.; MILÁN, E. P.; LUZ, K. G. \& GALVÃO, H. C. Manifestación oral recurrente de paracoccidioidomcosis sin compromiso pulmonar: reporte de caso y revisión de la literatura. Int. $J$. Odontostomat., 8(2):267-272, 2014.

RESUMEN: En este artículo se describe un caso de paracoccidioidomicosis crónica (PCM) recurrente 11 años después del diagnóstico inicial. La paciente una mujer blanca de Brasil de 51 años de edad, que había sido diagnosticada previamente con PCM. El examen físico reveló la presencia de una lesión única en el labio superior y una lesión elevada con apariencia de cicatriz fibrosa en la mucosa bucal derecha. No obstante el diagnóstico de PCM, la ausencia de compromiso pulmonar llevó a la biopsia de la lesión localizada en la mucosa bucal y el análisis histopatológico no demostró cambios morfológicos indicativos de cualquier lesión. Sin embargo, la citología exfoliativa teñida con Grocott-Gomori mostró la presencia de Paracoccidioides brasiliensis y la infección causada por este hongo fue probado. De esta manera, hacemos hincapié en la importancia de la evaluación odontológica para el diagnóstico de enfermedades que se manifiestan generalmente por vía sistémica. Por lo tanto, el diagnóstico correcto de las manifestaciones orales de PCM es esencial para asegurar la intervención temprana y segura.

PALABRAS CLAVE: paracoccidioidomicosis, paracoccidioides brasiliensis, micosis oral, citología exfoliativa.

\section{REFERENCES}

Almeida, O. P; Jacks, J. Jr. \& Scully, C. Paracoccidioidomycosis of the mouth: an emerging deep mycosis. Crit. Rev. Oral Biol. Med., 14(5):377-83, 2003.

André, D. C.; Lopes, J. D.; Franco, M. F.; Vaz, C. A. \& Calich, V. L. Binding of laminin to Paracoccidioides brasiliensis induces a less severe pulmonary paracoccidioidomycosis caused by virulent and low-virulence isolates. Microbes. Infect., 6(6):549-58, 2004.

Bicalho, R. N.; Santo, M. F.; de Aguiar, M. C. \& Santos, V. R. Oral paracoccidioidomycosis: a retrospective study of 62 Brazilian patients. Oral Dis., 7(1):56-60, 2001.

Borges-Walmsley, M. I.; Cheng, D.; Shu, X. \& Walmsley, A. $\mathrm{R}$. The pathobiology of Paracoccidioides brasiliensis. Trends Microbiol., 10(2):80-7, 2002.

Castro, L. G.; Müller, A. P.; Mimura, M. A. \& Migliari, D. A. Hard palate perforation: an unusual finding in paracoccidioidomycosis. Int. J. Dermatol., 40(4):281-3, 2001.

Coutinho, Z. F.; Silva, D. d.; Lazera, M.; Petri, V.; Oliveira, R. M.; Sabroza, P. C. \& Wanke, B. Paracoccidioidomycosis mortality in Brazil (1980-1995). Cad. Saude Publica, 18(5):1441-54, 2002.

de Abreu E Silva, M. À.; Salum, F. G.; Figueiredo, M. A.; Lopes, T. G.; da Silva, V. D. \& Cherubini, K. Interrelationship of clinical, histomorphometric and immunohistochemical features of oral lesions in chronic paracoccidioidomycosis. J. Oral Pathol. Med., 42(3):23542, 2013.

Franco, M.; Bagagli, E.; Scapolio, S. \& da Silva Lacaz, C. A critical analysis of isolation of Paracoccidioides brasiliensis from soil. Med. Mycol., 38(3):185-91, 2000.

Godoy, H. \& Reichart, P. A. Oral manifestations of paracoccidioidomycosis. Report of 21 cases from Argentina. Mycoses, 46(9-10):412-7, 2003.

de Oliveira Gondak, R.; Mariano, F. V.; dos Santos Silva, A. R.; Vargas, P. A. \& Lopes, M. A. Single oral paracoccidioidomycosis mimicking other lesions: report of eight cases. Mycopathologia, 173(1):47-52, 2012.

De Azevedo Izidoro, A. C.; Da Silva, P. C.; De Oliveira Ribas, M.; De Azevedo, L. R.; Machado, M. A. \& De Lima, A. A. 
S. Case of recurrent paracoccidioidomycosis in female. 10 years after initial treatment. Bull. Tokio Dent. Coll., 48(2):67-72, 2007.

Meneses-García, A.; Mosqueda-Taylor, A.; Morales-de la Luz, R. \& Rivera, L. M. Paracoccidioidomycosis: report of 2 cases mimicking squamous cell carcinoma. Oral Surg. Oral Med. Oral Pathol. Oral Radiol. Endod., 94(5):60913, 2002.

Neville, B. W.; Damm, D. D.; Allen, C. M. \& Bouquot, J. E. (Eds.). Oral \& Maxillofacial Pathology. 3rd ed. St. Louis, Saunders Elsevier, 2009.

Pagliari, C.; Fernandes, E. R.; Stegun, F. W.; da Silva, W. L.; Seixas Duarte, M. I. \& Sotto, M. N. Paracoccidioidomycosis: cells expressing IL17 and Foxp3 in cutaneous and mucosal lesions. Microb. Pathog., 50(5):263-7, 2011.

Peraçoli, M. T.; Kurokawa, C. S.; Calvi, S. A.; Mendes, R. P.; Pereira, P. C.; Marques, S. A. \& Soares, A. M. Production of pro- and anti-inflammatory cytokines by monocytes from patients with paracoccidioidomycosis. Microbes Infect., 5(5):413-8, 2003.

Roldán, J. C.; Tabares, A. M.; Gómez, B. L.; Aristizábal, B. E.; Cock, A. M. \& Restrepo, A. The oral route in the pathogenesis of paracoccidioidomycosis: an experimental study in BALB/c mice infected with P. brasiliensis conidia. Mycopathologia, 151(2):57-62, 2001.

Romano, C. C.; Mendes-Giannini, M. J.; Duarte, A. J. \& Benard, G. IL-12 and neutralization of endogenous IL10 revert the in vitro antigen-specificcellular immunosuppression of paracoccidioidomycosis patients. Cytokine, 18(3):149-57, 2002.

Rubin, R. \& Strayer, D. S. Rubin's Pathology: Clinicopathologic Foundations of Medicine. $5^{\text {th }}$ ed. Philadelphia, Lippincott Williams \& Wilkins, 2006.

Shikanai-Yasuda, M. A.; Telles Filho, Fde. Q.; Mendes, R. P.; Colombo, A. L. \& Moretti, M. L. Guidelines in paracoccidioidomycosis. Rev. Soc. Bras. Med. Trop., 39(3):297-310, 2006.

Silva, C. O.; Almeida, A. S.; Pereira, A. A.; Sallum, A. W.; Hanemann, J. A. \& Tatakis, D. N. Gingival involvement in oral paracoccidioidomycosis. J. Periodontol., 78(7):1229-34, 2007.

Van Damme, P. A.; Bierenbroodspot, F.; Telgtt, D. S.; Kwakman, J. M.; De Wilde, P. C. \& Meis, J. F. A case of imported paracoccidioidomycosis: an awkward infection in The Netherlands. Med. Mycol., 44(1):13-8, 2006.

Verli, F. D.; Marinho, S. A.; Souza, S. C.; Figueiredo, M. A. \&
Yurgel, L. S. Clinical-epidemiologic profile of paracoccidioidomycosis at the Stomatology Department of São Lucas Hospital, Pontificia Universidade Católica of Rio Grande do Sul. Rev. Soc. Bras. Med. Trop., 38(3):234-7, 2005

Correspondence to:

Hébel Cavalcanti Galvão

Departamento de Odontologia-UFRN

Programa de Pós-Graduação em Patologia Oral

Salgado Filho Avenue, 1787

Lagoa Nova CEP: 59.056-000, Natal-RN

BRAZIL

Email: hebel.galvao@yahoo.com.br

Received: 09-12-2013

Accepted: 12-05-2014 